\title{
Xylanases in diets with alternative feeds and energy reduction in commercial layers
}

\section{Xilanases em dietas com alimentos alternativos e redução energética para poedeiras comerciais}

\begin{abstract}
Gislaine da Cunha de Andrade ${ }^{1 *}$; Elis Regina de Moraes Garcia2; Charles Kiefer ${ }^{3}$; Fabiana Fonseca Zanoelo4; Giovana Cristina Giannesi"; Patrícia Gomes Santana ${ }^{1}$; Danilo de Souza Sanches ${ }^{1}$
\end{abstract}

\author{
Highlights \\ Xylanases for reduction of non-starch polysaccharides. \\ Energy reduction as an effect of carbohydrate use. \\ Alternative feeds for light commercial laying hens.
}

\begin{abstract}
The use of alternative ingredients has been increasing in a continuing attempt to reduce production costs, along with the use of additives, such as carbohydrases, for their possible positive effects on nutrient metabolization by layers. Thus, this study aimed to evaluate the effects of different xylanases in diets with reduced metabolizable energy (ME) and the inclusion of alternative ingredients on the metabolizability of nutrients in diets for commercial laying hens, by conducting two metabolism tests. In the first trial,100 layers hens were distributed in a fully randomized $2 \times 2+1$ factorial design (two metabolizable energy reductions $\times$ two xylanases, plus one control diet). In the second assay, 140 layer hens were distributed in a fully randomized $2 \times 3+2$ factor design (two xylanases $\times$ three ingredients, plus two control diets, positive and negative). It was concluded that supplementation with pantanal xylanase improved the metabolizability of nutrients in corn-based diets and soybean meal for light commercial layers, allowing for a reduction of up to $200 \mathrm{kcal} / \mathrm{kg}$ of ME in the diets. Xylanases are more effective on wheat bran enabling a decrease of 150 $\mathrm{kcal} / \mathrm{kg}$ of $\mathrm{ME}$ in commercial laying diets without affecting nutrient metabolizability. The action of pantanal xylanase in diets containing fibrous ingredients was similar to that of commercial xylanase.
\end{abstract}

Key words: Aspergillus japonicus. Carbohydrases. Exogenous enzymes. Metabolizability. Non-starch polysaccharides.

1 Students of the Master's Course of the Posgraduate Program in Animal Science, Universidade Estadual do Mato Grosso do Sul, UEMS, Aquidauana, MS, Brazil. E-mail: andrade.gislaine.ga@gmail.com; patriciagsantanaa@gmail. com; danilorzt9@gmail.com

2 Prof., UEMS, Aquidauana, MS, Brazil. E-mail: ermgarcia@uems.br

3 Prof., College of Veterinary Medicine and Animal Science, UFMS, Campo Grande, MS, Brazil. E-mail: charles.kiefer@ ufms.br

${ }^{4}$ Profs., College of Program in Biological Sciences, UFMS, Campo Grande, MS, Brazil. E-mail: ffzanoelo@hotmail.com; giannesigiovana@hotmail.com

* Author for correspondence

Received: Nov. 15, 2020 - Approved: May 28, 2021 


\section{Resumo}

O uso de ingredientes alternativos vem aumentando em uma tentativa contínua de reduzir os custos de produção, juntamente com o uso de aditivos, como os carboidrases, para seus possíveis efeitos positivos na metabolização de nutrientes por poedeiras. Assim, este estudo teve como objetivo avaliar os efeitos de diferentes xilanases em dietas com energia metabolizável reduzida (ME) e a inclusão de ingredientes alternativos sobre a metabolizabilidade de nutrientes em dietas para galinhas poedeiras comerciais, realizando dois testes de metabolismo. No primeiro ensaio, 100 aves foram distribuídas em delineamento inteiramente casualizado em esquema fatorial $2 \times 2+1$ (duas reduções de energia metabolizável $\times$ duas xilanases, mais uma dieta controle). No segundo ensaio, 140 aves foram distribuídas em delineamento inteiramente casualizado em esquema fatorial $2 \times 3+2$ (duas xilanases $\times$ três ingredientes -, mais duas dietas controle positivo e controle negativo). Conclui-se que a suplementação com xilanase do Pantanal melhora a metabolizabilidade dos nutrientes de dietas a base de milho e farelo de soja para poedeiras comerciais leves, possibilitando a redução em até $200 \mathrm{Kcal} / \mathrm{kg}$ de energia metabolizável das dietas. As xilanases são mais efetivas sobre o farelo de trigo e possibilitam a redução de $150 \mathrm{Kcal} / \mathrm{kg}$ de energia metabolizável nas dietas de poedeiras comerciais, sem prejuízo na metabolizabilidade dos nutrientes. Em dietas contendo ingredientes fibrosos a ação da xilanase do Pantanal é similar a xilanase comercial.

Palavras-chave: Aspergillusjaponicus. Carboidrases. Enzimas exógenas. Metabolizabilidade. Polissacarídeos não amiláceos.

\section{Introduction}

Brazil traditionally uses poultry feed consisting of corn and soybean meal, with up to $70 \%$ of these products in its formulation. However, since the effects of fluctuations in the prices of these ingredients affect the profitability of the industry, there is a need to search for more economically viable food sources. Wheat bran, rice bran, and soy husks are more affordable substitutes for maize in poultry diets (Santos, Gentilini, Ladeira, Anciuti, \& Rutz, 2017); however, these ingredients are rich in non-starch polysaccharides (NSPS), which have low digestibility for poultry and therefore hinder their use (Masey O'Neill, Smith, \& Bedford, 2014).

Arabinose and xylose are the main NSPs found in wheat bran $(6.49 \%$ and $10.76 \%$, respectively), rice bran (3.49\% and $4.09 \%)$, and soybean hulls (3.99\% and $7.68 \%$ ) (Rostagno et al., 2017). The presence of these NSPs in the gastrointestinal tract interferes with the rate of diffusion of endogenous enzymes because of the increased viscosity of the digestive tract. This change in the structure of the intestinal mucosa causes decreased metabolizability of nutrients and the appearance of enterobacteria (Sadeghi, Toghyani, \& Gheisari, 2015).

Although maize and soybean meal are highly digestible for poultry, these ingredients contain considerable amounts of NSPs (Saeed et al., 2019). Approximately $7 \%$ of NSPs can be found in corn, comprising $1.55 \%$ arabinose and $2.07 \%$ xylose, with $16.5 \%$ in soybean meal, comprising $2.39 \%$ arabinose and $1.53 \%$ xylose (Rostagno et al., 2017).

It is suggested that exogenous enzymes improve metabolizability, as well as the utilization of other nutrients such as proteins and amino acids; therefore, the industry has been investing in their use to 
increase the profitability of poultry activities. Numerous authors have demonstrated that the use of these additives can provide an improvement in the metabolizability of ingredients and the reduction in the viscosity of the digest at the ammonia level, as well as increase the endogenous enzymatic activity, improving the absorption capacity at the intestinal level when changing the microbial population, and consequently, improving the overall performance of poultry production (Mirzaie, Zaghari, Aminzadeh, Shivazad, \& Mateos, 2012; Ravindran, 2013; Bobeck, Nachtrieb, Batal, \& Persia, 2014; Sadeghi et al., 2015; Stefanello, Vieira, Carvalho, Sorbara, \& Cowieson, 2016).

Exogenous enzymes, such as $\beta$-glucanases, amylases, cellulases, xylanases, proteases, galactosidases, protease and lipases, each acting on a certain type of substrate, have been used to reduce the negative nutritional factors on bird performance. However, only carbohydrates ( $\beta$-glucanases, xylanases, and galactosides) can act as enzyme-substrate complexes, reducing the viscosity of the gastrointestinal system (Munir \& Maqsood, 2013), allowing for endogenous enzyme activity, increasing absorption and improving nutrient metabolizability. (Alagawany, Elnesr, \& Farag, 2018).

Among carbohydrates, xylanase has been gaining prominence because of its satisfactory results when added to diets containing high-viscosity grains, such as wheat, barley, and rye, as well as low-viscosity grains (Alagawany et al., 2018), such as corn (Pirgozliev, Bedford, \& Acamovic, 2010), since performance is maintained compared to that of non-enzyme diets, depending on its ability to improve energy metabolizability (Nian, Guo,
$\mathrm{Ru}, \mathrm{Li}$, \& Péron, 2011; Stefanello et al., 2016) and the intestinal health of the poultry (Guo, Liu, Zhao, Li, \& Guo, 2014).

The commonly used xylanases in the animal industry are produced by the fungus Aspergillus niger, and the bacteria Trichoderma reesei and Bacillus subtilis. Studies on the use of xylanases in poultry nutrition from filamentous fungi from the Cerrado/Pantanal biomesare pioneers since the subjecthas been poorly documented. The goal of this study was to evaluate the effects of different xylanases in energy-reduced diets and alternative foods on the metabolizability of nutrients and energy for commercial layers.

\section{Material and Methods}

The study was developed in the Demonstration Field of Poultry Production (CDPZ) and in the Laboratory of Quality of Animal Products of the State University of Mato Grosso do Sul, University Unit of Aquidauana, under the approval of the Ethics Committee on the Use of Animals (CEUA/UEDM), protocol No. 39/2017.

Two metabolism tests were performed on commercial layers of the Dekalb White lineage at 78 weeks of age, standardized by body weight $(1,400 \pm 100 \mathrm{~g})$ and production. The poultry were housed in conventional laying houses in galvanized wire cages with $25 \times 40 \times 45 \mathrm{~cm}$ divisions. A trough-type feeder was used and feed (Rostagno et al., 2017) was available ad libitum at 08:00 and 16:00 under the troughs for each experimental unit. The photoperiod consisted of $17 \mathrm{~h}$ of light per day (natural + artificial lighting). The temperature and humidity inside the houses were recorded at 08:00 and 16:00 using a hygrometer in the 
middle of the house between the production lines, with a maximum temperature of $32^{\circ} \mathrm{C}$ $\pm 3{ }^{\circ} \mathrm{C}$, minimum temperature of $13^{\circ} \mathrm{C} \pm 4{ }^{\circ} \mathrm{C}$, maximum relative humidity of $65 \% \pm 22$, and minimum relative humidity of $33 \% \pm 4$.

The excreta were collected for $5 \mathrm{~d}$ after the $5 \mathrm{~d}$ adaptation period using plastic bags placed under the cages. To determine the beginning and end of the collection, ferric oxide was used as a marker. The chemical composition of the ingredients used in the diets is presented in Table 1. Dry matter $(\mathrm{DM})$, mineral matter (MM), nitrogen $(\mathrm{N})$, and neutral detergent fiber (NDF) contents of the ingredients were determined according to methodologies described by Silva and Queiroz (2002). Crude energy (CE) was quantified by burning the sample in an adiabatic calorimetric pump, as described by Silva and Queiroz (2002).

\section{Table 1}

\section{Bromatological composition of ingredients}

\begin{tabular}{|ccccc|}
\hline Parameters & \multicolumn{4}{c|}{ Ingredients } \\
& Corn & Soybean meal & Soybean hulls & Wheat bran \\
\hline Dry Matter (\%) & 89,88 & 89,38 & 89,01 & 82,26 \\
\hline Crude Protein (\%) & 7,72 & 47,58 & 9,98 & 17,66 \\
\hline Neutral Detergent Fiber (\%) & 27,68 & 21,36 & 45,07 & 64,14 \\
Acid Detergent Fiber (\%) & 3,50 & 8,27 & 14,73 & 46,45 \\
\hline Ether extract (\%) & 14,20 & 7,60 & 9,70 & 12,70 \\
\hline Mineral Matter (\%) & 7,28 & 7,00 & 4,15 & 5,37 \\
Crude Energy (kcal/kg) & 3890 & 4678 & 3767 & 3987 \\
\hline
\end{tabular}

Test1

In the first metabolism trial, 100 layers were distributed in a fully randomized $2 \times 2+$ 1 factorial design (two levels of metabolizable energy reduction, 100 and $200 \mathrm{kcal} / \mathrm{kg} \mathrm{ME}$, two different xylanases, and a control diet without energy reduction and the inclusion of xylanase), totaling five experimental diets with five repetitions and four laying hens per experimental unit. The commercial xylanase (XC) used was obtained from the microorganism Trichoderma reesei, and the filamentous xylanase pantanal (XP) from the Pantanal region of the Cerrado was from
Aspergillus japonicus, both with inclusion fixed at $100 \mathrm{~g} / \mathrm{t}(16,000 \mathrm{BXU} / \mathrm{kg})$ of diet. The experimental diets consisted of a positive control diet (PC) based on corn and soybean meal, and negative control diets with a reduction of $100 \mathrm{kcal} / \mathrm{kg}$ of $\mathrm{ME}$ supplemented with XP $(100 \mathrm{~g} / \mathrm{t})$, a reduction of $100 \mathrm{kcal} / \mathrm{kg}$ of ME supplemented with XC (100 g/t), corn and soy bran with a reduction of $200 \mathrm{kcal} / \mathrm{kg} \mathrm{ME}$ supplemented with XP (100 g/t), and corn and soy bran with a reduction of $200 \mathrm{kcal} / \mathrm{kg} \mathrm{ME}$ supplemented with XC $(100 \mathrm{~g} / \mathrm{t})$. The results of the study are presented in Table: Diets were formulated to be isonutritive, except for sodium ( $\mathrm{Na})$, chlorine $(\mathrm{Cl})$, and potassium $(\mathrm{K})$, 
to meet the nutritional requirements of poultry according to Rostagno et al. (2017) and the lineage manual Dekalb White (2009) (Table 2).

Diet intake was calculated by the amount of diet offered during the collection period less the amount remaining at the end. The average daily intake was determined based on repetitions and treatments. Excreta were collected twice a day (08:00 and 16:00) to avoid fermentation by scraping, discarding dietary waste, feathers, or any contaminating material. The plastic bags with excreta were replaced with clean bags at each collection, and the samples were transferred to previously labeledplastic bags, weighed, and frozen.

The excreta were then thawed, homogenized, weighed by repetition, and samples were taken and placed in a forced ventilation oven for $72 \mathrm{~h}$ at $55^{\circ} \mathrm{C}$. The samples were then removed from the oven, weighed, ground, and stored for further laboratory analyses.

The DM, MM, N, NDF, diets, and excreta contents were determined according to the methodologies described by Silva and Queiroz (2002). The crudy energy (MCCE) of the diets and excreta was determined by sample burning using an adiabatic calorimetric pump. After obtaining the laboratory analysis of the diets and excreta, the apparent metabolizable energy (AME), the apparent metabolizable energy corrected for nitrogen balance (NPE), as well as the metabolizability coefficients of dry matter (MCDM), crude energy, crude protein (MCCP), ether extract (MCEE), neutral detergent fiber (MCNDF), acid detergent fiber (MCADF), and mineral matter (MCMM) were determined according to the equations described by Sakomura and Rostagno (2016):

$$
\begin{gathered}
A M E=\frac{\text { crude energy }(C E) \text { ingested }- \text { excreted } C E}{D M \text { ingested }} \text { and } \\
A M E n=\frac{\text { ingested } C E-(\text { excreted } C E+8.22 * N B),}{D M \text { ingested }}
\end{gathered}
$$

where $\mathrm{BN}$ (nitrogen balance) $=\mathrm{N}$ ingested - N excreted; MCDM, MCCE, MCCP, MCEE,
MCNDF, MCADF, and MCMM were calculated using the following equation:

$$
\operatorname{MCA}(\text { nutrient })=\frac{(\text { nutrient ingested }- \text { excreted nutrient }) \times 100}{\text { Nutrient ingested }}
$$


Table 2

Centesimal composition and calculated values of experimental diets

\begin{tabular}{|c|c|c|c|c|c|}
\hline \multirow{2}{*}{ Ingredient (\%) } & \multicolumn{5}{|c|}{ Reduction of the ME§ (Kcal/kg) } \\
\hline & Control & 100 & 100 & 200 & 200 \\
\hline Ground corn & 62,56 & 64,27 & 64,27 & 64,39 & 64,39 \\
\hline Soybean meal, $48 \%$ & 21,49 & 21,30 & 21,30 & 21,30 & 21,30 \\
\hline Limestone & 10,34 & 10,31 & 10,31 & 10,31 & 10,31 \\
\hline Bicalcium phosphate & 1,55 & 1,61 & 1,61 & 1,62 & 1,62 \\
\hline Salt & 0,50 & 0,50 & 0,50 & 0,50 & 0,50 \\
\hline Soy oil & 2,94 & 1,30 & 1,30 & - & - \\
\hline Vitamin trace mineral premix ${ }^{1}$ & 0,10 & 0,10 & 0,10 & 0,10 & 0,10 \\
\hline DL- Metionina (99\%) & 0,33 & 0,39 & 0,39 & 0,33 & 0,33 \\
\hline L-Lysin HCl (99\%) & 0,11 & 0,11 & 0,11 & 0,11 & 0,11 \\
\hline L-Triptofano (98\%) & 0,013 & 0,013 & 0,013 & 0,013 & 0,013 \\
\hline L-Threonine (98\%) & 0,070 & 0,079 & 0,079 & 0,079 & 0,079 \\
\hline $\mathrm{BHT}^{2}$ & 0,01 & 0,01 & 0,01 & 0,01 & 0,01 \\
\hline Inert & - & - & - & 1,57 & 1,57 \\
\hline$X P^{*}$ & - & 0,01 & - & 0,01 & - \\
\hline$X C^{* *}$ & - & - & 0,01 & - & 0,01 \\
\hline Total & 100 & 100 & 100 & 100 & 100 \\
\hline \multicolumn{6}{|c|}{ Calculated composition } \\
\hline $\mathrm{CE}^{3}(\mathrm{kcal} / \mathrm{kg})$ & 3.761 & 3.861 & 3.742 & 3.713 & 3.687 \\
\hline ME (kcal/kg) & 2.900 & 2.800 & 2.800 & 2.700 & 2.700 \\
\hline $\mathrm{CP}^{4}(\%)$ & 15,45 & 14,70 & 16,00 & 15,99 & 15,58 \\
\hline Lysine dig. & 0,78 & 0,78 & 0,78 & 0,78 & 0,78 \\
\hline Met + Cys dig. & 0,76 & 0,76 & 0,76 & 0,76 & 0,76 \\
\hline Tryptophan dig. & 0,18 & 0,18 & 0,18 & 0,18 & 0,18 \\
\hline Threonine dig. & 0,60 & 0,60 & 0,60 & 0,60 & 0,60 \\
\hline Crude Fiber (\%) & 2,06 & 2,08 & 2,08 & 2,08 & 2,08 \\
\hline Calcium (\%) & 4,43 & 4,43 & 4,43 & 4,43 & 4,43 \\
\hline Phosphorus disp. (\%) & 0,37 & 0,37 & 0,37 & 0,37 & 0,37 \\
\hline Sodium (\%) & 0,20 & 0,08 & 0,08 & 0,08 & 0,08 \\
\hline Chlorine (\%) & 0,36 & 0,19 & 0,19 & 0,19 & 0,19 \\
\hline Potassium (\%) & 0,65 & 0,65 & 0,65 & 0,66 & 0,66 \\
\hline $\mathrm{BED}^{5}$ & 152,39 & 150,86 & 150,86 & 151,01 & 151,01 \\
\hline $\mathrm{NSP}^{6}$ & 7,81 & 7,89 & 7,89 & 7,91 & 7,91 \\
\hline
\end{tabular}

$\S$ Metabolizable Energy ${ }^{1}$ Composition per kg of diet: Vitamin A 9.637 UI, Vitamin D3 2409 UI, Vitamin E 36,1 UI, Vitamin K3 1,93 mg, Vitamin B1 2,59 mg, Vitamin B2 6,44 mg, Vitamin B6 3.614 mg, Vitamina B12 0,0159 mg, Ac. Pantotênico 12,95 mg, Ac Nicotínico 39,2 mg, Ac, Fólico 0,903 mg, Biotina 0,090 mg, Colina 392 mg, Cu 8,37 mg, Fe 41,68 mg, I 0,843 mg, Mn 58,36 mg, Se 0,250 mg, Zn 54,21; ${ }^{2}$ Antioxidant; *Pantanal Xylanase; ** Commercial Xylanase; ${ }^{3}$ Crude Energy analyzed ${ }^{4}$ Crude Protein analyzed ${ }^{5}$ electrolytic balance of the diet (Mongin, 1981); ${ }^{6}$ Non- starch polysaccharides. 


\section{Statistics}

The data were subjected to an analysis of variance and when there was a significant interaction $(P<0.05)$ between the reductions of DM and the addition of enzymes, the pairwise data obtained were unfolded and the means were compared by the Tukey test $(P<0.05)$. In cases where the interaction was not significant, the effects of the factors were analyzed in isolation and subjected to analysis of variance and Tukey's test $(P<0.05)$. Subsequently, all means were compared using the Dunnett test $(P<0.05)$ with the control diet. The statistical program used in both tests was the University version (SAS University Edition, 2013).

\section{Test2}

In the second metabolizability trial, 140 layers were distributed in a completely randomized design with eight experimental diets, five repetitions, and four poultry per experimental unit. The experimental diets were as follows: PC diet based on corn and soybean meal; negative control diets (NC) based on: corn and soybean meal with a reduction of $150 \mathrm{kcal} / \mathrm{kg}$ of metabolizable energy; corn, soybean meal, and soybean meal with a reduction of $150 \mathrm{kcal} / \mathrm{kg}$ of $\mathrm{ME}$ supplemented with XP (100 g/t); maize, soybean meal, soybean bark, and wheat bran with a reduction of 150 $\mathrm{kcal} / \mathrm{kg}$ ME supplemented with XP (100 g/t); maize, soybean meal, and soybean bark with a reduction of $150 \mathrm{kcal} / \mathrm{kg}$ ME supplemented with XC (100 g/t); maize, soybean meal, and wheat bran with $150 \mathrm{kcal} / \mathrm{kg}$ ME reduction supplemented with XC (100 g/t); and maize, soybean meal, soybean meal, and wheat bran with $150 \mathrm{kcal} / \mathrm{kg} \mathrm{ME}$ reduction supplemented with XC (100 g/t) (Table 3).

Experimental diets were formulated to be isonutritive, except for fiber, $\mathrm{Na}, \mathrm{Cl}$, and $\mathrm{K}$, to meet the nutritional requirements of poultry according to Rostagno et al. (2017) and the lineage manual (Dekalb White, 2009). The second metabolism test followed the methodologies for bromatological analyses of the diets and excreta described in the first test. 
Table 3

Centesimal composition and calculated values of experimental diets with different alternative feeds

\begin{tabular}{|c|c|c|c|c|c|c|c|c|}
\hline \multirow{2}{*}{ Ingredient (\%) } & \multicolumn{8}{|c|}{ Reduction of $150 \mathrm{Kcal}$ EM§̧/kg inclusion with xylanase } \\
\hline & $P C^{*}$ & NC§ & $\mathrm{SH}^{1}$ & $\mathrm{WB}^{2}$ & SHWB 3 & $\mathrm{SH}$ & WB & SHWB \\
\hline Ground corn & 62,56 & 66,01 & 58,17 & 59,49 & 51,62 & 58,17 & 59,49 & 51,62 \\
\hline Soybean meal $48 \%{ }^{4}$ & 21,49 & 20,98 & 20,33 & 20,38 & 19,5 & 20,33 & 20,38 & 19,5 \\
\hline Wheat bran & - & - & - & 6,00 & 6,00 & - & 6,00 & 6,00 \\
\hline Soyhulls & - & - & 6,00 & - & 6,00 & 6,00 & - & 6,00 \\
\hline Limestone & 10,34 & 10,35 & 10,28 & 10,42 & 10,35 & 10,28 & 10,42 & 10,35 \\
\hline Bicalcium phosphate & 1,55 & 1,55 & 1,54 & 1,46 & 1,41 & 1,54 & 1,46 & 1,41 \\
\hline Salt & 0,50 & 0,50 & 0,50 & 0,50 & 0,50 & 0,50 & 0,50 & 0,50 \\
\hline Soy oil & 2,94 & 0,04 & 2,51 & 1,46 & 3,93 & 2,51 & 1,46 & 3,93 \\
\hline VMP 5 & 0,10 & 0,10 & 0,10 & 0,10 & 0,10 & 0,10 & 0,10 & 0,10 \\
\hline DL-Methionine (99\%) & 0,33 & 0,33 & 0,35 & 0,33 & 0,35 & 0,35 & 0,33 & 0,35 \\
\hline L-Lysine (99\%) & 0,11 & 0,12 & 0,12 & 0,13 & 0,13 & 0,12 & 0,13 & 0,13 \\
\hline L-Thriptophan (98\%) & 0,01 & 0,02 & 0,02 & 0,01 & 0,02 & 0,02 & 0,01 & 0,02 \\
\hline L-Threonine (98\%) & 0,07 & 0,07 & 0,09 & 0,08 & 0,10 & 0,09 & 0,08 & 0,10 \\
\hline $\mathrm{BHT}^{7}$ & 0,01 & 0,01 & 0,01 & 0,01 & 0,01 & 0,01 & 0,01 & 0,01 \\
\hline$X P^{* *}$ & - & - & 0,01 & 0,01 & 0,01 & - & - & - \\
\hline$X C^{* * *}$ & - & - & - & ----- & ----- & 0,01 & 0,01 & 0,01 \\
\hline Total & 100 & 100 & 100 & 100 & 100 & 100 & 100 & 100 \\
\hline \multicolumn{9}{|c|}{ Calculated composition } \\
\hline CE (kcal/kg) & 3.879 & 3.787 & 3.862 & 3.882 & 3.824 & 3.907 & 3.865 & 3.807 \\
\hline $\mathrm{ME}(\mathrm{kcal} / \mathrm{kg})^{9}$ & 2.900 & 2.750 & 2.750 & 2.750 & 2.750 & 2.750 & 2.750 & 2.750 \\
\hline $\mathrm{CP}^{10}(\%)$ & 16,03 & 15,70 & 19,03 & 16,83 & 18,81 & 16,86 & 18,35 & 18,09 \\
\hline Lysine dig & 0,78 & 0,78 & 0,78 & 0,78 & 0,78 & 0,78 & 0,78 & 0,78 \\
\hline Met + Cys dig & 0,76 & 0,76 & 0,76 & 0,76 & 0,76 & 0,76 & 0,76 & 0,76 \\
\hline Thryptophan dig & 0,18 & 0,18 & 0,18 & 0,18 & 0,18 & 0,18 & 0,18 & 0,18 \\
\hline Threonine dig & 0,60 & 0,60 & 0,60 & 0,60 & 0,60 & 0,60 & 0,60 & 0,60 \\
\hline Crude Fiber (\%) & 2,07 & 2,10 & 3,91 & 2,49 & 4,30 & 3,91 & 2,49 & 4,30 \\
\hline Calcium (\%) & 4,43 & 4,43 & 4,43 & 4,43 & 4,43 & 4,43 & 4,43 & 4,43 \\
\hline Phosphore disp. (\%) & 0,37 & 0,37 & 0,37 & 0,37 & 0,37 & 0,37 & 0,37 & 0,37 \\
\hline Sodium (\%) & 0,20 & 0,20 & 0,20 & 0,20 & 0,20 & 0,20 & 0,20 & 0,20 \\
\hline Chlorine (\%) & 0,37 & 0,37 & 0,36 & 0,37 & 0,36 & 0,36 & 0,37 & 0,36 \\
\hline Potassium (\%) & 0,65 & 0,65 & 0,62 & 0,68 & 0,64 & 0,62 & 0,68 & 0,64 \\
\hline BED $^{11}$ & 152,4 & 151,5 & 151,5 & 159,5 & 152,1 & 151,5 & 159,5 & 152,1 \\
\hline NSP 12 & 6,35 & 7,96 & 10,62 & 9,00 & 11,66 & 10,62 & 9,00 & 11,66 \\
\hline
\end{tabular}

$\S$ Metabolizable energy * Positive control; §Negative control; ${ }^{1}$ Soyhull; ${ }^{2}$ Wheat bran; ${ }^{3}$ Combination of the Soy hull and Wheat bran; ${ }^{4}$ Soybean meal 48\%; ${ }^{5}$ Vitamin trace mineral premix ${ }^{6}$ Composition per kg of diet: Vitamin A 9.637 UI, Vitamin D3 2409 UI, Vitamin E 36,1 Ul, Vitamin K3 1,93 mg, Vitamin B1 2,59 mg, Vitamin B2 6,44 mg, Vitamin B6 3.614 mg, Vitamin B12 0,0159 mg, Ac. Pantotênico 12,95 mg, Ac Nicotínico 39,2 mg, Ac, Fólico 0,903 mg, Biotina 0,090 mg, Colina 392 mg, Cu 8,37 mg, Fe 41,68 mg, I 0,843 mg, Mn 58,36 mg, Se 0,250 mg, Zn 54,21; ${ }^{7}$ Antioxidante; ${ }^{* *}$ Pantanal xylanase; ${ }^{* *}$ Commercial xylanase; ${ }^{8}$ Crude Energy analyzed; ${ }^{9}$ Metabolizable energy; ${ }^{10}$ Crude Proteinan analyzed; ${ }^{11}$ electrolytic balance of the diet (Mongin, 1981); ${ }^{12}$ Non- starch polysaccharides. 


\section{Statistics}

The data were subjected to analysis of variance and when there was an interaction $(P<0.05)$ between enzyme supplementation and the addition of alternative ingredients, the data obtained were unfolded and the means were compared by the Tukey test $(P<0.05)$. In the case of non-significant interactions, the effects of the factors were analyzed in isolation, subjected to analysis of variance, and Tukey's test $(P<0.05)$. Subsequently, all means were compared using the Dunnett test $(P<0.05)$ with the $P C$ diet and again with the NC diets. The statistical program used in both trials was the University version (SAS University Edition, 2013).

\section{Results and Discussion}

Test1

The MCDM of XP-supplemented diets was $2.2 \%$ higher than that of $X C$, and energyreduced and XP-supplemented diets did not differ from that of the control $(P>0.05)$. Considering diet composition, increased inclusion of soy oil in the control diet may have provided extra caloric effects, which could justify higher values compared to XCsupplemented diets in the 100 and $200 \mathrm{kcal}$ reductions of $\mathrm{ME}$.

This effect was justified by the inclusion of different enzymes for the metabolizability of dry matter since with an energy reduction of $100 \mathrm{kcal} / \mathrm{kg}$ of ME in both supplements, the amount of vegetable oil included remained the same; thus, the diets with XP showed greater effectiveness even with energy reductions equal to the PC (Table 4). In the present study, only the diet supplemented with XP in both reductions demonstrated effectiveness in equalization to the PC. The MCDM reflects the metabolizability of nutrients; decreased metabolizability indicates lower absorption and utilization of nutrients (Barbosa et al., 2014).

When in contact with non-amylaceous polysaccharides (NPAs), the main constituents of the plant cell wall are not digested by the poultry digestive system because of their hydrolysis-resistant bonds (Alagawany et al., 2018). Xylanases act on these by decreasing the viscosity of the digestive system, since the hydrolysis points are substrate-dependent, thereby improving the absorption of nutrients (Masey O'Neill et al., 2014). The results obtained for MCDM demonstrated that XP was efficient in hydrolyzing the arabinoxylans (the main substrate for xylanases) present in experimental diets, allowing the efficient action of exogenous enzymes to generate energy for ME reductions when compared to the control diet.

The values obtained for the MCCP of the diets supplemented with XP were $5.83 \%$ higher than those of supplementation with $\mathrm{XC}$ $(\mathrm{P}<0.05)$. However, compared to the control diet, only the diet with an energy reduction of $200 \mathrm{kcal}$ of ME/kg and supplemented with XP showed superior results for this variable. This result indicated that XP was effective in increasing the protein metabolizability of diets, possibly by reducing anti-nutritional factors (NSP) in corn and soybean meal. By hydrolyzing NSPs, xylanase allows the unavailable protein to be digested and amino acids to be absorbed, improving the MCCP (Varzaru, Panaite, Cornescu, \& Olteanu, 2019). 
Table 4

Energy values and metabolizability coefficients of diets for commercial laying hens, supplemented or not with different xylanases

\begin{tabular}{|c|c|c|c|c|c|c|c|c|c|}
\hline \multirow[b]{2}{*}{ Variables } & \multirow[b]{2}{*}{ ENZ } & \multicolumn{4}{|c|}{ Reductions of $\mathrm{ME}^{\S}$} & \multicolumn{4}{|c|}{ Probabilities } \\
\hline & & Control & $\begin{array}{c}100 \\
\mathrm{kcal} / \mathrm{kg}\end{array}$ & $\begin{array}{c}200 \\
\mathrm{kccal} / \mathrm{kg}\end{array}$ & Medium & ME & ENZ & INT. & CV\% ${ }^{1}$ \\
\hline \multirow{3}{*}{$\begin{array}{c}\mathrm{MCDM}^{2} \\
(\%)\end{array}$} & $X P$ & 77,41 & 77,86 & 77,89 & $77,87 a$ & & & & \\
\hline & $x C$ & & $76,33^{*}$ & $76,02^{*}$ & $76,17 b$ & 0,680 & 0,010 & 0,770 & 1,63 \\
\hline & Medium & & 77,09 & 76,85 & & & & & \\
\hline \multirow{3}{*}{$\begin{array}{c}\mathrm{MCCP}^{3} \\
(\%)\end{array}$} & XP & 62,75 & 62,00 & $66,33^{*}$ & $64,16 a$ & & & & \\
\hline & $\mathrm{XC}$ & & 61,58 & 60,98 & $60,42 b$ & 0,140 & 0,029 & 0,060 & 4,91 \\
\hline & Medium & & 61,79 & 63,65 & & & & & \\
\hline \multirow{3}{*}{$\begin{array}{c}\mathrm{MCEE}^{4} \\
(\%)\end{array}$} & XP & 86,00 & 84,78 & 84,95 & $84,86 a$ & & & & \\
\hline & XC & & $80,72^{*}$ & $80,33^{*}$ & $80,52 b$ & 0,847 & 0,001 & 0,606 & 2,97 \\
\hline & Medium & & 82,75 & 82,55 & & & & & \\
\hline \multirow{3}{*}{$\begin{array}{l}\text { MCNDF5 }^{5} \\
\text { (\%) }\end{array}$} & XP & 50,45 & $58,34 \mathrm{Bb}^{*}$ & $62,72 \mathrm{Aa}^{*}$ & 60,53 & & & & \\
\hline & $\mathrm{XC}$ & & $60,19 \mathrm{Aa}^{*}$ & $52,62 \mathrm{Bb}$ & 56,41 & 0,201 & 0,004 & 0,002 & 7,31 \\
\hline & Medium & & 59,26 & 57,67 & & & & & \\
\hline \multirow{3}{*}{$\begin{array}{c}\text { MCADF }^{6} \\
\text { (\%) }\end{array}$} & XP & 30,09 & $45,60^{*}$ & 30,44 & 38,02 & & & & \\
\hline & $\mathrm{XC}$ & & $42,19^{*}$ & 31,16 & 36,67 & 0,002 & 0,618 & 0,446 & 22,79 \\
\hline & Medium & & $43,49 A$ & $30,80 \mathrm{~B}$ & & & & & \\
\hline \multirow{3}{*}{$\begin{array}{c}\mathrm{MCMM}^{7} \\
(\%)\end{array}$} & XP & 53,42 & $46,43^{*}$ & 49,53 & 47,98 & & & & \\
\hline & $\mathrm{XC}$ & & $44,54^{*}$ & $48,20^{*}$ & 46,37 & 0,039 & 0,283 & 0,853 & 6,74 \\
\hline & Medium & & $45,48 B$ & $48,86 \mathrm{~A}$ & & & & & \\
\hline \multirow{3}{*}{$\begin{array}{c}\text { MCCE }^{8} \\
(\%)\end{array}$} & XP & 77,84 & 78,62 & 77,92 & $78,27 a$ & & & & \\
\hline & XC & & $76,00^{*}$ & $75,34^{*}$ & $75,67 b$ & 0,217 & 0,001 & 0,970 & 2,26 \\
\hline & Medium & & 77,31 & 76,63 & & & & & \\
\hline \multirow{3}{*}{$\begin{array}{c}\mathrm{AME}^{9} \\
(\mathrm{kcal} / \mathrm{kg})\end{array}$} & XP & 2932 & $3036^{*}$ & 2916 & $2976 a$ & & & & \\
\hline & XC & & $2823^{*}$ & $2778^{*}$ & $2801 b$ & 0,003 & 0,001 & 0,070 & 1,46 \\
\hline & Medium & & $2929 A$ & 2858B & & & & & \\
\hline \multirow{3}{*}{$\begin{array}{l}\text { AMEn }^{10} \\
(\mathrm{kcal} / \mathrm{kg})\end{array}$} & XP & 2777 & $2895 \mathrm{Aa}^{*}$ & $2610 \mathrm{Ba}^{*}$ & 2752 & & & & \\
\hline & XC & & $2526 \mathrm{Ab}^{*}$ & 2478Bb* & 2502 & 0,001 & 0,001 & 0,001 & 6,61 \\
\hline & Medium & & 2711 & 2544 & & & & & \\
\hline
\end{tabular}

${ }^{1}$ Coefficient of variation; * Differ from diet control by Dunnett test $(P<0,05)$; $A, B, a, b-$ Averages followed by the same letters, case in the row and lowercase in the column do not differ significantly by the Tukey test $(P<0,05)$. $\$$ Metabolizable energy;MCDM ${ }^{2}$-metabolizability coefficient of dry matter;MCCP ${ }^{3}$-metabolizability coefficient of crude protein;MCEE ${ }^{4}$-metabolizability coefficient of Ether Extract;MCNDF ${ }^{5}$-metabolizability coefficient of neutral detergent fiber;MCADF ${ }^{6}$-metabolizability coefficient of acid detergent fiber;MCMM ${ }^{7}$-metabolizability coefficient of mineral matter;MCCE ${ }^{8}$-metabolizability coefficient of crude energy;AME ${ }^{9}$-apparent metabolizable energy;AMEn ${ }^{10}$ - apparent metabolizable energy corrected for nitrogen. 
The metabolizability of proteins is directly influenced by the NSPs present in diets; therefore, by catalyzing dietary arabinoxylans, the enzyme allows amino acids, previously encapsulated in the cell walls of corn and soybean meal, to become readily available to perform the action of endogenous proteases, reducing endogenous production, which may be a secondary result of the xylanase response (Yaghobfar \& Kalantar, 2017).

The inclusion of $\mathrm{XP}$ in the diets improved the MCEE by $5.11 \%$ compared to that of XC. Only the diets with lower energy content supplemented with XC had lower MCEE values than the control diet. Stefanello et al. (2016) observed that broiler chicken diets based on corn and soybean meal or based only on corn supplemented with fungal xylanase (Aspergillus oryzae) had an MCEE comparable to that of non-supplemented diets, and there was an interaction between the supplementation of different xylanases and the energetic reduction of diets for MCNDF $(P<0.05)$.

The diet with a reduction of $200 \mathrm{kcal} /$ kgME, when supplemented with XP, presented values $6.9 \%$ higher than that of the 100 $\mathrm{kcal} / \mathrm{kg}$ reduced diet. The reduction of 100 $\mathrm{kcal}$ of ME/kg and supplementation with XC presented $12.5 \%$ higher results in relation to the diet with a reduction of $200 \mathrm{kcal}$ of ME/ $\mathrm{kg}$ and supplemented with XC. These outcomes demonstrated that xylanase was effective in metabolizing NDF in energy-reduced diets.

Additionally, in the control diet, only the diet supplemented with xylanase XC, with a reduction of $200 \mathrm{kcal}$ of ME/kg, was similar. The other diets with an energy reduction of 100 and $200 \mathrm{kcal}$ and supplemented with
$\mathrm{XP}$, and a reduction of $100 \mathrm{kcal}$ of $\mathrm{ME} / \mathrm{kg}$ supplemented with XC had an MCNDF of 13.5, which was $19.6 \%$ and $16.2 \%$ higher $(P<0.05)$, respectively, in comparison to the control diet.

NSPs can be classified according to their solubility in water; those soluble can be represented by hemicellulose and are present on the walls of foods of vegetable origin, which is composed mainly of arabinoxylans. Soluble fibers are indigestible by nonruminants at the intestinal level, which could explain the reduction in food energy use, and consequently, impair the absorption of minerals and affect the metabolism of lipids. However, the efficient digestion of soluble fibers may be directly reflected in the results of other metabolizability coefficients (Lima et al., 2019).

Exogenous enzymes that produce the intracellular nutrients contained in the plant wall can enhance the mechanism of action of endogenous enzymes (Guo et al., 2014). These results demonstrate that the improvement in MCNDF is influenced by the degradation of NSPs, and consequently, the MCDM obtained in this study.

Diets with an energy reduction of 100 kcal of ME/kg had higher MCADF than the diets with $200 \mathrm{kcal}$ of ME/kg, independent of the supplemented xylanase. Only diets containing 2,800 kcal of ME supplemented with XP or XC had an AFC $34.0 \%$ and $28.7 \%$ higher than the control diets, respectively. However, diets containing 2,700 kcal of ME supplemented with XP or XC exhibited values of ME MCADF similar to that of control diets with $2,900 \mathrm{kcal}$ of ME. A likely hypothesis for the increased ADF metabolizability is the solubilizing of much of the fiber in acid detergent by exogenous enzymes (Sousa et al., 2019). 
The MCMM of the diets with a reduction of $200 \mathrm{kcal}$ of $\mathrm{ME} / \mathrm{kg}$ was $6.91 \%$ higher compared to those with an energy reduction of $100 \mathrm{kcal} / \mathrm{kg}$, which could be attributed to the presence of inert components in the composition of the diets with higher energy reduction. According to Alagawany et al. (2018), an inert ingredient (kaolin) could contain a range of minerals that positively influence the MCMM of the diets, where as these minerals were not included in the energy reduction of $200 \mathrm{kcal} / \mathrm{kg}$ of DM.

MCNDF directly influenced the MCMM because soluble fiber is not hydrolyzed by enzymatic action and increases the rate of passage and the viscosity of the digest, thereby carrying more minerals, which are prevented from being absorbed by the poultry. The opposite is true when the soluble fiber is satisfactorily hydrolyzed, and the minerals are reduced and absorbed in greater quantities by the poultry. The diet with a reduction of $200 \mathrm{kcal}$ of ME/kg and supplemented with XP showed MCMM similar to that of the control diet, whereas the other diets showed lower results.

This result can be justified because soluble fiber (NSPs) has a strong capacity for ionic bonds with mineral elements that negatively interfere with its absorption by poultry (Broch et al., 2015). In turn, xylanase enzymes are capable of catalyzing and releasing monosaccharide NSPs (Alagawany et al., 2018), preventing the deleterious effects on the absorption of minerals; the results observed in this study indicate that the overall improvement in metabolizability coefficients may have been influenced by the degradation of NSPs because the MCDM values show the metabolizability coefficients observed for PC, $\mathrm{EE}, \mathrm{NDF}$, and ADF.
The effects of the addition of enzymes on MCCE $(P<0.05)$ were verified, with values $3.3 \%$ higher for $\mathrm{XP}$ than for $\mathrm{XC}$. In comparison to the control diet, the MCCE of the diets with lower energy levels and supplemented with $\mathrm{XC}$ were lower, whereas the XP-supplemented diets in both energy reductions exhibited no statistical differences.

The XP-supplemented diets showed an improvement of $175 \mathrm{kcal} / \mathrm{kg}$ of $\mathrm{AME}$ compared to those supplemented with XC. However, the formulated diets with a $100 \mathrm{kcal}$ $\mathrm{ME} / \mathrm{kg}$ reduction showed a $71 \mathrm{kcal} / \mathrm{kg}$ AME value higher than that of the $200 \mathrm{kcal} \mathrm{ME} / \mathrm{kg}$ reduction. Therefore, it can be inferred that supplementation with XP was efficient for supplying AME in the diets with lower energy values. In comparison to the control, only the diet formulated with a reduction of $100 \mathrm{kcal}$ of $\mathrm{ME} / \mathrm{kg}$ supplemented with XP exhibited superiority in AME values; diets supplemented with $\mathrm{XC}$ with energy reductions of $100 \mathrm{kcal}$ of $\mathrm{ME} / \mathrm{kg}$ and $200 \mathrm{kcal}$ of ME/kg had lower values.

By unfolding the interaction, it was verified that the inclusion of the enzymes XP and $X C$ in diets with an energy reduction of 100 kcal resulted in an increase of 285 and $48 \mathrm{kcal}$ of AMEn in relation to diets with a reduction of $200 \mathrm{kcal}$ of ME/kg. However, the values for AMEn were higher for energy-reduced and XP-supplemented diets compared to that of $X C$. The values of AMEn were influenced by the action of the enzyme XP with a reduction of $100 \mathrm{kcal}$ of $\mathrm{ME} / \mathrm{kg}$, demonstrating that the results of the diets with lower energy density and supplementation with xylanases were efficient in increasing the use of nutrients and improving the availability of energy.

The calculated energy values are higher than the determined AMEn. From the 
results obtained in this study and considering that the calculated values were based on natural matter, it is possible to infer that the AME values determined in the diets containing XP and with reductions of 100 and $200 \mathrm{kcal}$ of ME were higher and similar, respectively, to that of the control diet. This result supports the effectiveness of the XP enzyme in supplying energy deficits; however, the same effectiveness was not observed for the enzyme XC since it exhibited lower AME results than the control diet.

Additionally, the XP-supplemented diet with an energy reduction of $100 \mathrm{kcal} \mathrm{ME} /$ $\mathrm{kg}$ provided $118 \mathrm{kcal}$ of AMEn improvement over the control diet. XC-supplemented diets with an energy reduction of $100 \mathrm{kcal} \mathrm{ME} / \mathrm{kg}$ and $200 \mathrm{kcal} \mathrm{ME} / \mathrm{kg}$ provided $251 \mathrm{kcal}$ and 299 kcal AMEn less, respectively, and the XP-supplemented diet at the $200 \mathrm{kcal} \mathrm{ME} / \mathrm{kg}$ reduction was $167 \mathrm{kcal}$ less than that of the control diet.

The literature shows the possibility of energy reduction of up to $200 \mathrm{kcal} / \mathrm{kg}$ of ME in the diet containing $\mathrm{XP}$, which is higher than the absolute majority of reductions observed in the studies: up to $100 \mathrm{kcal}$ of ME/kg (Souza et al., 2012), 120 (Iwahashi et al., 2011), 125 (Cowieson, 2010), 145 (Viana et al., 2011), and $154 \mathrm{kcal}$ of ME/kg (Bobeck et al., 2014).

\section{Test 2}

The MCDM of the diets with a reduction of $150 \mathrm{kcal}$ of ME/kg containing wheat bran (WB) was $4.25 \%$ and $3.46 \%$ higher, respectively, than those with the addition of soybean hulls (SH) or soybean hulls and wheat bran (SHWB) (Table 5).
Diets supplemented with XP along with $\mathrm{SH}$, WB or SHWB and those supplemented with $\mathrm{XC}$ with the addition of $\mathrm{SH}$ or SHWB showed lower values than those supplemented with PC. In contrast, the diet containing WB and supplemented with $X C$ presented MCDM similar to that of the $\mathrm{PC}$, suggesting that the enzyme was possibly effective in hydrolyzing the arabinoxylans present in this experimental diet because the amount of NSPs was higher than that in the PC due to the presence of WB (Table 3).

This result indicated that energy generated from the release of monosaccharides from the hydrolysis of arabinoxylans by XC was able to reduce ME. In comparison to the NC, diets supplemented with XP and XC containing SH or SHWB had lower MCDM compared to diets supplemented with WB. In the present study, the amount of NSPs in experimental diets containing WB was lower than the others containing $\mathrm{SH}$ and SHWB supplemented with XP and XC (Table 3), which could explain the higher MCDM compared to NC.

The benefits of xylanase supplementation in wheat-based diets for layers have been extensively reviewed (Adeola \& Cowieson, 2011; Ravindran, 2013; Kiarie, Walsh, \& Nyachoti, 2016). The increased viscosity of the intestinal digest caused by the amount of NSPs is considered the most important mechanism for the low utilization of wheat bran (Yaghobfar \& Kalantar, 2017). Wheat-based diets have more than twice the concentration of NSPs than corn-based diets and soybean meal, implying a higher viscosity of the digestive tract in poultry (Lima et al., 2019). 
Table 5

Energy values and metabolizability coefficients of diets based on corn, soybean meal and alternative foods for commercial laying hens supplemented or not with Pantanal xylanase (XP) and commercial xylanase (XC)

\begin{tabular}{|c|c|c|c|c|c|c|c|c|c|c|c|}
\hline \multirow[b]{2}{*}{ Variables } & \multirow[b]{2}{*}{$\mathrm{PC}^{1}$} & \multicolumn{4}{|c|}{ Reductions $150 \mathrm{Kcal}$ EM/kg } & \multirow[b]{2}{*}{$\mathrm{SH}+\mathrm{WB}^{6}$} & \multirow[b]{2}{*}{ Medium } & \multicolumn{4}{|c|}{ Probabilities } \\
\hline & & $\mathrm{NC}^{2}$ & $\mathrm{ENZ}^{3}$ & $\mathrm{SH}^{4}$ & WB $^{5}$ & & & $\mathrm{ING}^{7}$ & ENZ & $\mathrm{INT}^{8}$ & $\mathrm{CV} \%{ }^{9}$ \\
\hline \multirow{3}{*}{$\begin{array}{c}\mathrm{MCDM}^{10} \\
(\%)\end{array}$} & & & $X P$ & $67,54^{\star \S}$ & $70,37^{*}$ & $68,97 * \S$ & 68,96 & & & & \\
\hline & 72,91 & 72,01 & $\mathrm{XC}$ & $68,03^{* \S}$ & 71,22 & $67,72^{\star \S}$ & 68,99 & 0,008 & 0,599 & 0,490 & 2,69 \\
\hline & & & Medium & $67,78 \mathrm{~B}$ & $70,79 \mathrm{~A}$ & $68,34 \mathrm{~B}$ & & & & & \\
\hline \multirow{3}{*}{$\begin{array}{c}\mathrm{MCCP}^{11} \\
(\%)\end{array}$} & & & $\mathrm{XP}$ & $55,06 \mathrm{Ba}$ & $53,51 \mathrm{Cb}$ & $56,86 \mathrm{Aa}$ & 55,14 & & & & \\
\hline & 57,18 & 56,54 & $\mathrm{XC}$ & $55,40 \mathrm{Ba}$ & $58,31 \mathrm{Aa}$ & $53,35 \mathrm{Cb}$ & 55,69 & 0,815 & 0,629 & 0,018 & 5,70 \\
\hline & & & Medium & 55,23 & 55,91 & 55,10 & & & & & \\
\hline \multirow{3}{*}{$\begin{array}{c}\text { MCEE }^{12} \\
(\%)\end{array}$} & & & $X P$ & $78,11 \mathrm{Bb}$ * & $75,30 \mathrm{Cb}^{*}$ & $82,96 A a^{\S}$ & 78,79 & & & & \\
\hline & 82,47 & 77,14 & XC & 79,07Ba & $78,50 \mathrm{Ca}^{*}$ & $80,52 A b^{\S}$ & 79,36 & 0,001 & 0,414 & 0,009 & 3,70 \\
\hline & & & Medium & 78,59 & 76,90 & 81,74 & & & & & \\
\hline \multirow{3}{*}{$\begin{array}{c}\text { MCNDF }^{13} \\
\text { (\%) }\end{array}$} & & & $X P$ & $34,03 \mathrm{Cb}^{\star \S}$ & $46,97 \mathrm{Ba}$ & $53,85 \mathrm{Aa}$ & 44,95 & & & & \\
\hline & 49,05 & 47,61 & XC & $40,65 \mathrm{Ba}^{\star \S}$ & $45,34 \mathrm{Aa}$ & $39,64 \mathrm{Cb}^{\star \S}$ & 41,87 & 0,002 & 0,150 & 0,001 & 18,27 \\
\hline & & & Medium & 37,34 & 46,15 & 46,74 & & & & & \\
\hline \multirow{3}{*}{$\begin{array}{c}\text { MCADF }^{14} \\
\text { (\%) }\end{array}$} & & & $\mathrm{XP}$ & $23,75 \mathrm{Cb}^{\star \S}$ & $53,69 A a^{\star \S}$ & $45,40 \mathrm{Ba}^{*}$ & 40,95 & & & & \\
\hline & 59,91 & 46,87 & $x C$ & $35,45 \mathrm{Ca}^{\star \S}$ & $46,25 A b^{*}$ & $36,24 \mathrm{Bb}^{\star \S}$ & 39,31 & 0,001 & 0,352 & 0,001 & 26,59 \\
\hline & & & Medium & 29,60 & 49,97 & 40,82 & & & & & \\
\hline \multirow{3}{*}{$\begin{array}{c}\mathrm{MCMM}^{15} \\
(\%)\end{array}$} & & & $X P$ & $23,87 \mathrm{Bb}^{\star \S}$ & $36,14 A b^{\S}$ & $34,97 \mathrm{Ab}^{\S}$ & 31,66 & & & & \\
\hline & 41,94 & 43,97 & $x C$ & $37,37 \mathrm{Aa}$ & $40,44 \mathrm{Aa}$ & $35,40 A a^{\S}$ & 37,74 & 0,030 & 0,010 & 0,003 & 20,50 \\
\hline & & & Medium & 30,62 & 38,29 & 35,18 & & & & & \\
\hline \multirow{3}{*}{$\begin{array}{c}\mathrm{MCCE}^{16} \\
(\%)\end{array}$} & & & $X P$ & $70,13^{\star \S}$ & $69,61^{\star \S}$ & $69,58^{\star \S}$ & 69,77 & & & & \\
\hline & 74,29 & 73,78 & $\mathrm{XC}$ & $70,14^{\star \S}$ & 72,77 & $68,62^{\star \S}$ & 70,51 & 0,050 & 0,350 & 0,060 & 2,33 \\
\hline & & & Medium & $70,13 B$ & $71,19 \mathrm{~A}$ & $69,10 \mathrm{C}$ & & & & & \\
\hline \multirow{3}{*}{$\begin{array}{c}\mathrm{AME}^{17} \\
(\mathrm{kcal} / \mathrm{kg})\end{array}$} & & & $X P$ & $2708^{* \S}$ & $2702^{\star \S}$ & $2661^{* \S}$ & 2690 & & & & \\
\hline & 2882 & 2794 & $x C$ & 2740 *\$ & $2853^{\S}$ & $2612^{\star \S}$ & 2735 & 0,010 & 0,290 & 0,057 & 2,73 \\
\hline & & & Medium & 2724B & 2783A & $2637 C$ & & & & & \\
\hline \multirow{3}{*}{$\begin{array}{l}\text { AMEn }^{18} \\
(\mathrm{kcal} / \mathrm{kg})\end{array}$} & & & $X P$ & $2507 \mathrm{Bb}^{\star \S}$ & $2547 A b^{\star \S}$ & $2472 \mathrm{Ca}^{\star \S}$ & 2509 & & & & \\
\hline & 2737 & 2646 & $x C$ & $2545 B a^{* \S}$ & $2650 A^{*}$ & $2410 \mathrm{Cb}^{\star \S}$ & 2535 & 0,080 & 0,010 & 0,001 & 3,93 \\
\hline & & & Medium & 2526 & 2598 & 2441 & & & & & \\
\hline
\end{tabular}

${ }^{1}$ Positive control; ${ }^{2}$ Negative control; ${ }^{3}$ Enzymes; ${ }^{4}$ Soyhull; ${ }^{5}$ Wheat bran; ${ }^{6}$ Soyhull and Wheat bran; ${ }^{7}$ Ingredient; ${ }^{8}$ Interaction; ${ }^{9}$ Coefficient of variation; * Differ from diet control by Dunnett test $(P<0,05) ; A, B, a, b-$ Averages followed by the same letters, case in the row and lowercase in the column do not differ significantly by the Tukey test $(P<0,05)$. MCDM $10_{-}$ metabolizability coefficient of dry matter; MCCP ${ }^{11}$-metabolizability coefficient of crude protein; MCEE ${ }^{12}$-metabolizability coefficient of Ether Extract; MCNDF ${ }^{13}$-metabolizability coefficient of neutral detergent fiber; MCADF ${ }^{14}$-metabolizability coefficient of acid detergent fiber; MCMM ${ }^{15}$-metabolizability coefficient of mineral matter; MCCE ${ }^{16}$-metabolizability coefficient of crude energy; AME ${ }^{17}$-apparent metabolizable energy; AMEn ${ }^{18}$-apparent metabolizable energy corrected for nitrogen. 
Evaluating the effects of xylanase, glucanase, and phytase in the diet of light laying hens, Lima et al. (2019), observed that enzymatic supplementation is efficient for light laying, similar to the present study.

There was a significant interaction for MCCP such that diets containing WB, when supplemented with $\mathrm{XC}$, were $8.23 \%$ higher than those with XP supplementation. The SHWB and XP supplemented diets were $6.17 \%$ higher than those of the SHWB and XC. However, diets with $\mathrm{SH}, \mathrm{XC}$, and $\mathrm{XP}$ supplementation showed no difference in MCCP. There was no significant difference between energy-reduced diets containing alternative ingredients and supplemented with xylanases and PC and NC diets.

The increase in the metabolizability of $\mathrm{PC}$ is related to the reduction in the production of endogenous amino acids, demonstrating that xylanases are efficient in reducing this production through a secondary effect, in which they improve the use of the protein content resulting from diets, there by improving digestion processes and directly affecting the metabolizability of nutrients (Masey O'Neill et al., 2014). Therefore, supplementation with XC was effective in improving the metabolizability of proteins, and consequently, their absorption due to the action of anti-nutritional factors (Souza et al., 2012).

The diets containing the combination of SHWB presented MCEE 3.85\% and 5.92\% higher than the diets with $\mathrm{SH}$ and $\mathrm{WB}$, respectively. Diets containing $\mathrm{SH}$ and $\mathrm{WB}$ supplemented with $X P$, and WB supplemented with $X C$ provided lower metabolizability of the ether extract relative to that of the PC. The MCEE of the NC diet was lower than that of the diets containing SHWB supplemented with XP and XC.
Evaluating the productive performance and nutrient digestibility of broilers fed xylanase-supplemented diets, GhayourNajafabadi, Khorravinia, Gheisari, Azarfar and Khanahmadi (2018) observed no statistical differences for the MCEE, in contrast with the results obtained in this study.

For the MCNDF, it was found that the diet formulated with SHWB and supplemented with $\mathrm{XP}$ was $36.8 \%$ higher than the diet containing $\mathrm{SH}$, and $12.8 \%$ higher than the diet containing WB. XC supplementation with WB provided $10.3 \%$ and $12.6 \%$ higher metabolizability of NDF compared to diets containing $\mathrm{SH}$ and $\mathrm{SHWB}$, respectively. The diet supplemented with XP and the addition of $\mathrm{SH}$ showed the poorest results in relation to the other diets supplemented with XP and XC.

In comparison to control diets, it was observed that the diet with $\mathrm{SH}$ addition and XP supplementation differed from that of the $P C$, presenting lower MCNDF, along with the diets supplemented with $\mathrm{XC}$ and $\mathrm{SH}$ and SHWB in combination, whereas the other diets did not statistically differ from that of the PC. Similar to PC, XP supplemented WB, SHWB supplemented and XC supplemented WB diets did not differ statistically.

The diet containing SHWB exhibited a higher concentration of NSPs compared to those with SH (9.0\%) and WB (22.8\%). However, PC (45.5\%) and NC (31.7\%) diets presented a lower concentration in relation to that of the others, since PC and NC diets were based on corn and soybean meal, and the difference was based on the composition of alternative foods rich in NSPs.

SHWB and WB contain considerable concentrations of NSPs (Rostagno et al., 2017), which could explain the superior result 
of the metabolizability of NDF in relation to diets containing only $\mathrm{NC}$, evidencing the improvement by the supplementation of XP in encapsulating the anti-nutritional factors present in these ingredients that are directly related to the results for $\mathrm{MCDM}, \mathrm{MCCP}, \mathrm{MCEE}$, $M C C E, A M E$, and AMEn.

For the MCADF, it was found that diets containing WB supplemented with XP were positively influenced by the action of the enzyme, with values $55.8 \%$ and $15.44 \%$ higher, respectively, than diets containing $\mathrm{SH}$ and SHWB supplemented with XP. Diets containing $\mathrm{SH}$ and SHWB were $23.4 \%$ and $21.6 \%$ lower than those containing WB supplemented with XC. Compared to the PC, all diets were statistically lower and in relation to $\mathrm{NC}$, only the XP supplemented, and WB supplemented diets were higher, as the others were statistically lower.

When evaluating fiber source and xylanase on performance, egg quality, and gastrointestinal tract of laying hens, Sousa et al. (2019) stressed that the ADF digestibility coefficient may be influenced by the presence of xylanase in diets containing alternative ingredients. However, in the present study, diets formulated with alternative ingredients had lower MCADF compared to NC and PC which may be justified by the higher fiber content in their composition.

All diets containing alternative foods supplemented with $\mathrm{XC}$ were found to have higher MCMM than those supplemented with $\mathrm{XP}$, whereas lower MCMM values were found in diets containing SH supplemented withXP. This result is possibly correlated with the amount of NSPs in this experimental diet and with the metabolizability of NDF and ADF since this diet had the lowest MCNDF, MCADF, and MCMM.
Thus, the low metabolizability of mineral matter is directly correlated with mineral loading at the intestinal level, which could explain these results and the ineffectiveness of the enzyme in encapsulating the anti-nutritional factors present in soybean hulls.

According to Sinha, Kumar, Makkar, De Boeck and Becker (2011), several components of NSP sinter act with minerals by decreasing the absorption of $\mathrm{Ca}, \mathrm{Mg}, \mathrm{Na}$, and P. Additionally, the viscosity of the digestive tract induced by the presence of NSPs in the gastrointestinal tract of poultry may negatively influence the absorption of minerals, indicating that a large amount of NSPs at the intestinal level negatively affect the effective interaction between endogenous enzymes and the intestinal mucosal surface, leading to longer digestion time in the intestine and reduced mineral content, impairing nutrient absorption. Additionally, long exposure of the intestine to this anti-nutritional factor may reduce villous length, increase intestinal crypt depth in the jejunum and ileum, and increase the rate of intestinal mucosal cell renewal, impairing nutrient absorption (Moghaddam, Salari, Arshami, Golian, \& Maleki, 2012; Kalantar, Khajali, \& Yaghobfar, 2015; Rehman et al., 2017).

The diet supplemented with XP containing SH showed a lower result for MCMM compared to PC, which is likely associated with the amount of fiber, and consequently, NSPs of this alternative food. In turn, the NC differed from XP supplemented diets and the addition of $\mathrm{SH}, \mathrm{WB}$, and $\mathrm{SHWB}$, as well as from $X C$ supplemented diets with the addition of SHWB, all of which showed lower results. Only the XC supplemented, and $\mathrm{SH}$ and WB supplemented diets did not differ statistically. 
As for MCCE, diets with WB inclusion were higher than those with $\mathrm{SH}(1.5 \%)$ and SHWB (3.0\%) supplemented with XP and XC. Compared to $\mathrm{PC}$ and $\mathrm{NC}$, diets containing $\mathrm{SH}, \mathrm{WB}$, and SHWB supplemented with XP, as well as those containing $\mathrm{SH}$ and $\mathrm{SHWB}$ supplemented with XC showed lower results. Evaluating nutrient digestibility for laying hens, Sousa et al. (2019) concluded that the addition of xylanase to high-fiber diets inhibits the metabolizability of nutrients. Similar results were observed in this study, where diets with higher fiber levels (addition of SH and SHWB) showed lower results for MCCE, even with supplementation with xylanases. The MCCE of the diets containing $\mathrm{SH}, \mathrm{WB}$, and SHWB was lower than that of

The PC and NC diets. This result was probably associated with a higher amount of NSP present in the alternative ingredients, such as wheat bran (24.0\%) and soybean hulls (55.0\%) than corn (7.0\%) and soybean meal 48\% (16.5\%) (Rostagno et al., 2017).

Experimental diets with the addition of $\mathrm{SH}$ and $\mathrm{WB}$ and supplementation of $\mathrm{XP}$ and XC xylanases provided higher AME values (87 kcal and $146 \mathrm{kcal}$ ) compared to diets with the addition of the combination of SHWB. The supplementation of $\mathrm{XP}$ and $\mathrm{SH}, \mathrm{WB}$, and SHWB diets showed lower energy values than that of $\mathrm{PC}$, as well as those supplemented with $\mathrm{XC}$ containing $\mathrm{SH}$ and SHWB. Only the experimental diet with the addition of WB supplemented with $\mathrm{XC}$ ha dim proved $\mathrm{AME}$ values from the PC, while the other diets had lower AME values.

These results could be correlated with the hydrolysis of the NSPs present in WB using XC supplementation, making it possible to supply the energy reduction in the diet, and equating to PC. The greater effectiveness of $\mathrm{XC}$ in hydrolyzing the arabinoxylans present in WB was directly linked to the results obtained for MCNDF; the enzyme interacts with the anti-nutritional factor, making it possible to release the encapsulated nutrients from the soluble fiber, thereby releasing them in small units (sugar polymers) which are used by the poultry, providing higher values with superior metabolizability coefficients for the NDF.

The unfolding of the interaction for AMEn demonstrated that the diet containing WB was positively influenced by $\mathrm{XC}$ supplementation. Diets including $\mathrm{SH}$ and SHWB supplemented with XP and XC showed lower values of AMEn. However, diets with a combination of SHWB supplemented with XP or XC had considerably lower AMEn values than the other diets. This result was in line with the metabolizability coefficients that may be correlated with diet composition because the amount of NSPs is higher in diets containing $\mathrm{SH}$, and their metabolizability is lower in several coefficients, such as MCNDF, MCADF and MCMM, despite enzyme supplementation.

Diets with reduced levels of $\mathrm{ME}$ supplemented with xylanases had lower values of AMEn than PC, which may be correlated with energy reductions and the effectiveness of exogenous enzymes in interacting with the nutritional factors present in alternative feeds. It may also be correlated with the composition of the NC diet because it was based on corn and soy meal, which both have a lower amount of NSP than the other diets. Thus, according to this result, diets with alternative foods may have affected the AMEn values.

AME and AMEn were directly correlated with the values of the metabolizability 
coefficients. The diet supplemented with $\mathrm{XC}$ and addition of WB demonstrated its effectiveness in the most varied coefficients, with the best results for this feed. Additionally, the action of the enzyme XC contrasts that of MCDM, in which only this diet was not statistically different from $\mathrm{PC}$ and $\mathrm{NC}$; therefore, greater enzymatic effectiveness on the metabolizability coefficient could be correlated with the amount of NSPs hydrolyzed, which allowed it to supply an energetic reduction of $150 \mathrm{kcal}$ of ME/ $\mathrm{kg}$ in the present study.

Additionally, the lack of endogenous enzymes could compromise the energy content of foods by maintaining energygenerating nutrients, such as carbohydrates, lipids, and proteins, within their encapsulated structures by the anti-nutritional factor (Lima et al., 2019). Diets with enzyme complex supplementation demonstrated that MCDM and AMEn were superior in diets with enzyme supplementation compared to diets without supplementation. In the present study, the results were similar for AME and AMEn in, in which the NC diet was statistically equivalent to the diets containing xylanase and inclusion of alternative food, as well as the PC diet.

In the literature, the possibility of energy reduction of up to $150 \mathrm{kcal}$ in a diet containing $\mathrm{XP}$ is effective in relation to the most absolute reductions observed in studies. However, other authors observed a reduction of less than $150 \mathrm{kcal} / \mathrm{kg}$ of ME; Vandeplas, Dauphin, Thonart, Théwis and Beckers (2010) showed a reduction of $93 \mathrm{kcal} / \mathrm{kg}$ of ME. Other authors observed no difference with the inclusion of xylanases in wheat-based diets, including Mirzaie et al. (2012).

\section{Conclusion}

Through this study, it was possible to evidence that xylanases enzymes can be used as tools to restore the nutritional value of diets adjusted for the lowest energy level and improve the metabolizability of diets formulated with corn and soybean meal, as well as for diets formulated with alternative ingredients such as soybean hulls and wheat bran.

It was concluded that XP supplementation $(16,000 \mathrm{BXU} / \mathrm{kg})$ improved the metabolizability of nutrients in corn-based diets and soybean meal for light commercial layers, enabling the reduction of up to 200 $\mathrm{kcal} \mathrm{ME} / \mathrm{kg}$ of diets; xylanases $(16,000 \mathrm{BXU} / \mathrm{kg})$ were more effective on WB-containing diets and allowed for a reduction of $150 \mathrm{Kcal} / \mathrm{kg}$ of $\mathrm{ME}$, providing improved metabolizability of nutrients for light commercial layers. In diets containing fibrous ingredients, the action of $\mathrm{XP}$ is similar to that of $\mathrm{XC}$.

Further studies should be conducted to evaluate higher reductions in ME in laying hen diets with xylanases, in order to establish nutritional matrix diets.

\section{Acknowledgements}

The authors are grateful to the Fundação de Apoio ao Desenvolvimento do Ensino, Ciência e Tecnologia do Estado de Mato Grosso do Sul (FUNDECT) and the Msc grant that allowed this study by conducted; Conselho Nacional de Desenvolvimento Científico e Tecnológico (CNPq); State University of Mato Grosso do Sul and Federal University of Mato Grosso do Sul. "This study was financed by the Coordenação de 
Aperfeiçoamento de Pessoal de Nível Superior - Brasil (CAPES; Finance Code 001)".

\section{References}

Adeola, O., \& Cowieson, A. J. (2011). Boardinvited review: opportunities and challengesinusing exogenous enzymes to improve non-ruminant animal production. Journal of Animal Science, 89(10), 31893218. doi: 10.2527/jas.2010-3715

Alagawany, M., Elners, S. H. S., \& Farag, M. R. (2018). The role of exogenous enzymes in promoting growth and improving nutrient digestibility in poultry. Iranian Journal Veterinary Research, 19(3), 157-164. Retrieved from https://www.ncbi.nlm.nih. gov/pmc/articles/PMC6184034/

Barbosa, N. A. A., Bonato, M. A., Sakomura, N. K., Dourado, L. R. B., Fernandes, J. B. K., \& Kawauchi, I. M. (2014). Digestibilidade ileal de frangos de corte alimentados com dietas suplementadas com enzimas exógenas. Comunicata Scientiae, 5(4), 361-369. doi: 10.14295/cs.v5i4.460

Bobeck, E. A., Nachtrieb, A. B., Batal, A. B., \& Persia, M. E. (2014). Effects of xylanase supplementation of corn-soybean meal-dried distiller's grain diets on performance, metabolizable energy, and body composition when fed to first cycle laying hens. Journal of Applied Poultry Research, 23(2), 174-180. doi: 10.3382/ japr.2013-00841

Broch, J., Oliveira, N. T. E., Nunes, R. V., Henz, J. R., Silva, I. M., Frank. R., \& Schone, R. A. (2015). Chemical composition and energetic values of wheat and its subproducts for broiler chicken. Semina:
Ciências Agrárias, 36(5), 3481-3488. doi: 10.5433/1679-0359.2015v36n5p3481

Cowieson, A. J. (2010). Strategic selection of exogenous enzymes for corn/ soy-based poultry diets. Journal of Poultry Science, 47(1), 1-7. doi: 10.2141/jpsa.009045

Dekalb White (2009). Manual de manejo das poedeiras Dekalb White. Recuperado de https://www.fcav.unesp.br/Home/depar tamentos/zootecnia/NILVAKAZUESAKO MURA/manual_dekalb_white.pdf

Ghayour-Najafabadi, P., Khorravinia, H., Gheisari, A., Azarfar, A., \& Khanahmadi, M. (2018). Productive performance, nutrient digestibility and intestinal morphometry in broiler chickens fed corn or wheat-based diets supplemented with bacterial-orfungal originated xylanase. Italian Journal of Animal Science, 17(1), 165-174. doi: 10. 1080/1828051X.2017.1328990

Guo, S., Liu, D., Zhao, X., Li, C., \& Guo, Y. (2014). Xylanase supplementation of a wheatbased diet improved nutrient digestion and mRNA expression of intestinal nutrient transporters in broiler chickens infected with Clostridium perfringens. Poultry Science, 93(1), 94-103. doi: 10. 3382/ps.2013-03188

Iwahashi, A. S., Furlan, A. C., Scherer, C., Ton, A. P. S., Lorençon, L., \& Scapinello, C. (2011). Utilização de complexo enzimático em dietas para codornas de corte. Acta Scientiarum. Animal Science, 33(3), 273279. doi: 10.4025/actascianimsci.v33i3. 11216

Kalantar, M., Khajali, F., \& Yaghobfar, A. (2015). Different dietary source of nonstarch polysaccharides supplemented with enzymes affected growth and carcass traits, blood parameters and gut 
physicochemical properties of broilers. Global Journal of Animal Scientific Research, 3(2), 412-418. Retrieved from http://www.journals.wsrpublishing.com/ index.php/gjasr/article/view/357

Kiarie, E., Walsh, M. C., \& Nyachoti, C. M. (2016). Performance, digestive function and mucosal responses to selected feed additives for pigs. Journal of Animal Science, 94(3), 169-180. doi: 10.2527/jas. 2015-9835

Lima, M. R., Costa, F. G. P., Vieira, D. V. G., Cardoso, A. S., Lima, G. S., Cavalcante, D. T.,... Kaneko, I. N. (2019). Xylanase, glucanase, and phytase in the diet of light laying hens. Journal of Applied Poultry Research, 28(4), 1150-1155. doi: 10.3382/ japr/pfz081

Masey O'Neill, H. V., Smith, J. A., \& Bedford, M. R. (2014). Multicarbohydrase enzymes for non- ruminants. Asian-Australasian Journal of Animal Science, 27(2), 290301. doi: 10.5713/ajas.2013.13261

Mirzaie, S., Zaghari, M., Aminzadeh, S., Shivazad, M., \& Mateos, G. G. (2012). Effects of wheat inclusion and xylanase supplementation of the diet on productive performance, nutrient retention, and endogenous intestinal enzyme activity of laying hens. Poultry Science, 91(2), 413425. doi: 10.3382/ps.2011-01686

Moghaddam, H. N., Salari, S., Arshami, J., Golian, A., \& Maleki, M. (2012). Evaluation of the nutritional value of sunflower meal and its effect on performance, digestive enzyme activity, organ weight, and histological alterations of the intestinal villi of broiler chickens. Journal Applied Poultry Research, 21(2), 293-304. doi: 10.3382/japr.2011-00396
Mongin, P. (1981). Recent Advances in dietary anion-cation balance: application in poultry. Procedure Nutrition Society, 40(1), 285-294.

Munir, K., \& Maqsood, S. (2013). A review on role of exogenous enzyme supplementation in poultry production. Emirates Journal of Food and Agriculture, 25(1), 66-80. doi: 10.9755/ejfa.v25i1.9138

Nian, F., Guo, Y. M., Ru, Y. J., Li, F. D., \& Péron, A. (2011). Effect of exogenous xylanase supplementation on the performance, net energy and gut microflora of broiler chickens fed wheat-based diets. AsianAustralasian Journal of Animal Science, 24(3), 400-406. doi: 10.5713/ajas.2011. 10273

Pirgozliev, V., Bedford, S. R., \& Acamovic, T. (2010). Effect of dietary xylanase on energy, amino acid and mineral metabolism, and egg production and quality in laying hens. British Poultry Science, 51(5), 639-647. doi: 10.1080/ 00071668.2010 .514325

Ravindran, V. (2013). Feed enzymes: the science, practice, and metabolic realities. Journal Applied Poultry Research, 22(3), 628-636. doi: 10.3382/japr.2013-00739

Rehman, Z. U., Kamran, J., Abd El-Hack, M. E., Alagawany, M., Bhatti, S. A., Ahmad, G.,... Ding, C. (2017). Influence of low protein and amino acid diets with different sources of protease on performance, carcasses and nitrogen retention of broiler chickens. Animal Production Science, 58(9), 16251631. doi: 10.1071/AN16687

Rostagno, H. S., Albino, L. F. T., Hannas, M. I., Donzele, J. L., Sakomura, N. K., Perazzo, F. G.,... Brito, C. O. (2017). Tabelas brasileiras para aves e suínos (composição de 
alimentos e exigências nutricionais). Viçosa, MG: Editora UFV.

Sadeghi, A., Toghyani, M., \& Gheisari, A. (2015). Effect of various fiber types and choice feeding of fiber on performance, gut development, humoral immunity, and fiber preference in broiler chicks. Poultry Science, 94(11), 2734-2743. doi: 10.3382/ ps/pev292

Saeed, M., Ayasan, T., Alagawany, M., Abd ElHack, M. E., Abdel-Latif, M., Arain, M. A., \& Chao, S. (2019). The role of B-mannanase (Hemicell) in improving poultry productivity, health hand environment. Brazilian Journal of Poultry Science, 21(3), 1-8. doi: 10.1590/1806-9061-2019-1001

Sakomura, N. K., \& Rostagno, H. S. (2016). Métodos de pesquisa em nutrição de monogástricos. Jaboticabal, SP: FUNEP.

SAS University Edition (2013). Statistical analyses System-SAS. Retrieved from https://www.sas.com/pt_br/software/uni versity-edition/download-software.html.

Santos, V. L., Gentilini, F. P., Ladeira, S. R. L., Anciuti, M. A., \& Rutz, F. (2017). Complexo enzimático e farelo de arroz integral sobre o desempenho produtivo e qualidade dos ovos de poedeiras em segundo ciclo de produção. Revista Ciência Animal Brasileira, 18(1), 1-10. doi: 10.1590/1089$6891 v 18 \mathrm{e}-18117$

Silva, D. J., \& Queiroz, A. C. (2002). Análises de alimentos (métodos químicos e biológicos). Viçosa, MG: Editora UFV.

Sinha, A. K., Kumar, V., Makkar, H. P. S., De Boeck, G., \& Becker, K. (2011). Nonstarch polysaccharides and their role in fish nutrition - a review. Food Chemistry, 127(4), 1409-1426. doi: 10.1016/j.food chem.2011.02.042
Sousa, L. S., Carvalho, T. S. M., Nogueira, F. A., Saldanha, M. M., Vaz, D. P., Bertechini, A. G., Lara, L. J. C. (2019). Fiber source and xylanase on performance, egg quality, and gastrointestinal tract of laying hens. Revista Brasileira de Zootecnia, 48(1), 1-10. doi: 10.1590/rbz4820170286 Retrieved from https:// www.scielo.br/pdf/ rbz/v48/1806-9290-rbz-48-e20170286. pdf

Souza, K. M. R., Faria, D. E., Nakagi, V. S., Carão, A. C. P., Pacheco, B. H. C., Trevisan, R. B., \& Gomes, G. A. (2012). Metabolizable energy values of diets supplemented with xylanase determined with laying hens. Revista Brasileira de Zootecnia, 41(12), 2433-2440. doi: 10.1590/S151635982012001200008

Stefanello, C., Vieira, S. L., Carvalho, P. S., Sorbara, J. O. B., \& Cowieson, A. J. (2016). Energy and nutrient utilization of broiler chickens fed corn-soybean meal and corn-based diets supplemented with xylanase. Poultry Science, 95(8), 18811887. doi: $10.3382 / p s / p e w 070$

Vandeplas, S., Dauphin, R. D., Thonart, P., Théwis, A., \& Beckers, Y. (2010). Effect of the bacterial or fungal origin of exogenous xylanases supplemented to a wheatbased diet on performance of broiler chickens and nutrient digestibility of the diet. Canadian Journal of Animal Science, 90(2), 221-228. doi: 10.4141/CJAS09067

Varzaru, I., Panaite, T. D., Cornescu, G. M., \& Olteanu, M. (2019). Apparent faecal digestibility of essential amino acids from $\Omega 3$ pufa diets for laying hens. Brazilian Journal of Poultry Science, 21(3), 1-8. doi: 10.1590/1806-9061-2019-1025 
Viana, M. T. S., Albino, L. F. T., Rostagno, H. S., Silva, E. A., Vieira, R. A., \& Ribeiro, V., Jr. (2011). Utilização de xilanase em dietas compostas por milho e farelo de soja de poedeiras comerciais em postura. Revista Brasileira de Zootecnia, 40(2), 386-390. doi: 10.1590/S1516-35982011 000200021
Yaghobfar, A., \& Kalantar, M. (2017). Effect of non-starch polysaccharide (NSP) of wheat and barley supplemented with exogenous enzyme blend on growth performance, gut microbial, pancreatic enzyme activities, expression of glucose transporter (SGLT1) and mucin producer (MUC2) genes of broiler chickens. Revista Brasileira de Ciência Agrícola, 19(4), 629638. doi: 10.1590/1806-9061-2016-0441 